\title{
RETROSPECTIVE ANALYSIS OF SLOVENIAN MYCOBACTERIUM AVIUM COMPLEX AND MYCOBACTERIUM ABSCESSUS COMPLEX ISOLATES AND MOLECULAR RESISTANCE PROFILE
}

\author{
S. Truden ${ }^{a}$, M. Žolnir-Dovča ${ }^{2}$ E. Sodja ${ }^{a}$, M. Starčič Erjavec ${ }^{b}$ \\ ${ }^{a}$ University Clinic of Respiratory and Allergic Diseases Golnik, Golnik, Slovenia \\ ${ }^{b}$ University of Ljubljana, Ljubljana, Slovenia
}

\begin{abstract}
Mycobacteria belonging to Mycobacterium (M.) avium complex (MAC) and M. abscessus complex (MABSC) are the most frequent causes of mycobacteriosis in the world. In the last few years MAC and MABSC taxonomy was rapidly changing due to new molecular methods conveying the possibility to differentiate between species. New techniques are able to identify $M$. chimaera that was previously recognized as $M$. intracellulare and also differentiate subspecies of MABSC. Due to their natural habitat, non-tuberculous mycobacteria (NTM) are constantly exposed to various concentrations of antimicrobial drugs and other chemicals and consequently they had developed different mechanisms of resistance. Macrolides and aminoglycosides are frequently used drugs to treat MAC and MABSC infections. The aim of our nation-wide survey was to obtain information about MABSC subspecies prevalence in Slovenia and to assess the percentage of misidentifications of M. chimaera isolates as M. intracellulare in the past. Moreover, the purpose of our study was to reveal, which of the two species M. intracellulare or M. chimaera is clinically more relevant in Slovenia. Further, the aim of the study was to detect mutations in erm(41), rrl and $r r s$ genes, which are known to convey macrolide resistance (erm(41) and $r r l)$ and aminoglycoside resistance ( $r r s)$. One hundred and thirty-two Slovenian mycobacterial isolates obtained from the National Mycobacterial Collection that belong to MAC and MABSC were analysed. GenoType NTM-DR was used to differentiate M. intracellulare from M. chimaera and subspecies of MABSC. Our results showed that $48 \%$ of previously identified M. intracellulare isolates were actually M. chimaera isolates and that M. abscessus subsp. abscessus was the most frequent subspecies of MABSC. Most of the MABSC isolates carried the inducible macrolide resistance genes (erm(41) and $r r l)$, however none of the isolates of MAC and MABSC had mutations in rrs genes for aminoglycoside resistance.
\end{abstract}

Key words: nontuberculous mycobacteria, Mycobacterium abscessus, Mycobacterium avium, macrolide resistance, aminoglycoside resistance, nation-wide study.

\author{
Адрес для переписки: \\ Сара Труден \\ Голник 36, 4204 Голник, Словения, Национальная референс- \\ лаборатория, Университетская клиника респираторных \\ и аллергических заболеваний. \\ Тел.: +386 42569 409. Факс: +386 42569117 . \\ E-mail: sara.truden@klinika-golnik.si
}

\section{Библиографическое описание:}

Труден С., Жолнир-Довч М., Содья Э., Старчич Эрьявец М.

Ретроспективный анализ словенских изолятов Mycobacterium avium complex и Mycobacterium abscessus complex и молекулярный профиль устойчивости // Инфекция и иммунитет. 2018. Т. 8, № 4. С. 447-451. doi: $10.15789 / 2220-7619-2018-4-447-451$

(c) Truden S. et al., 2018

\author{
Contacts: \\ Sara Truden \\ Golnik 36, 4204 Golnik, Slovenia, National Reference Laboratory, \\ University Clinic of Respiratory and Allergic Diseases. \\ Phone: +386 42569 409. Fax: +386 42569117. \\ E-mail: sara.truden@klinika-golnik.si
}

Citation:

Truden S., Žolnir-Dovč M., Sodja E., Starčič Erjavec M. Retrospective analysis of Slovenian Mycobacterium avium complex and Mycobacterium abscessus complex isolates and molecular resistance profile // Russian Journal of Infection and Immunity = Infektsiya i immunitet, 2018, vol. 8, no. 4, pp. 447-451. doi: 10.15789/2220-7619-2018-4-447-451 


\section{PЕTРОСПЕКТИВНЫЙ АНАЛИЗ СЛОВЕНСКИХ ИЗОЛЯТОВ МYСОВАСТЕRIUM AVIUM COMPLEX И МYСОВАCTERIUM ABSCESSUS COMPLEХ И МОЛЕКУЛЯРНЫЙ ПРОФИЛЬ УСТОЙЧИВОСТИ}

\section{Труден С. ${ }^{1}$, Жолнир-Довч М. ${ }^{1}$, Содья Э. ${ }^{1}$, Старчич Эрьявец М. ${ }^{2}$}

${ }^{1}$ Университетская клиника респираторных и аллергических заболеваний Голник, г. Голник, Словения

2 Люблянский университет, Любляна, Словения

Резюме. Микобактерии, принадлежащие к Mycobacterium avium complex (MAC) и Mycobacterium abscessus complex (MABSC), являются наиболее частыми причинами микобактериоза в мире. В последние несколько лет таксономия MAC и MABSC быстро менялась в результате появления новых молекулярно-генетических методов, позволяющих выявлять различия в пределах вида. Это позволило идентифицировать вид M. chimae$r a$, который ранее относили к M. intracellulare, а также дифференцировать подвиды MABSC. Нетуберкулезные микобактерии являются типичными обитателями окружающей среды и в значительной мере подвержены воздействию различных концентраций противомикробных препаратов и других химических веществ, что привело к развитию различных механизмов природной резистентности. Макролиды и аминогликозиды наиболее часто используются для лечения инфекций, вызванных МАС и MABSC. Целью общенационального исследования являлась оценка распространенности подвидов MABSC в Словении, а также выявление случаев ошибочной идентификации изолятов M. chimaera как M. intracellulare ранее. Вместе с тем целью работы было выявить, какой из двух видов M. intracellulare или M. chimaera являлся клинически значимым на территории Словении, а также обнаружение мутаций в генах erm(41), rrl и rrs, которые, как известно, ассоциированы с развитием устойчивости к макролидам (erm(41) и rrl) и аминогликозиду (rrs). Нами были проанализированы 132 изолята MAC и MABSC, полученных из Национальной коллекции микобактерий Словении. GепоТуре NTM-DR использовался для дифференциации видов M. intracellulare и M. chimaera, а также подвидов МАBSC. Результаты исследования показали, что 48\% изолятов, ранее идентифицированных как M. intracellulare, относились к виду M. chimaera; наиболее распространенным подвидом МАВSС являлся M. abscessus subsp. abscessus. Большинство изолятов MABSC обладали генами устойчивости к макролидам (erm (41) и rrl), однако ни один из изолятов MAC и MABSC не выявлено мутаций устойчивости к аминогликозиду в гене rrs.

Ключевые слова: нетуберкулезные микобактерии, Mycobacterium abscessus, Mycobacterium avium, резистентность, макролиды, аминогликозиды, общенациональное исследование.

\section{Introduction}

Non-tuberculous mycobacteria (NTM) are environmental microorganisms that colonise different surfaces and can be isolated from soil, natural waters, air, household plumbing systems, animals and human specimens too. They are resistant to many disinfectants and antibiotics and therefore many infections caused by NTM cannot be cured with commonly used antibiotics [1]. They are causing diseases especially among immunocompromised patients.

Among Mycobacterium (M.) avium complex (MAC) there are two well known species causing disease in humans, M. avium and $M$. intracellulare. In 2004, development of more specific molecular methods revealed a new species among MAC, $M$. chimaera. Previously $M$. chimaera was, due to similar phenotypic and genotypic characteristics, misidentified as $M$. intracellulare. When $M$. chimaera was first described in 2004 by Tortoli et al. [11] it was estimated that it is a highly virulent species. Afterwards results showed that M. intracelullare was more virulent than $M$. chimaera $[9,11]$. In MAC, genes connected with macrolide and aminoglycoside resistance are $r r l$ and $r r s$, respectively [6]. In 2012 $M$. chimaera caused two invasive infections after cardiac surgery [8]. Afterwards more than 100 cases of $M$. chimaera infections were revealed in European countries and around the world. This opportunistic pathogen became linked with heater-cooler units (HCUs) used during cardiac surgeries. M. chimaera has preferences to colonise warm, humid surfaces where it forms biofilms and has high potential to aerosolize. During surgeries, HCUs produce aerosols and $M$. chimaera is dispersed into the air and can colonize the patient. Due to M. chimaera's slowgrowth, it can take even several years after surgery to develop disease $[4,8]$.

Mycobacterium abscessus, belonging to M. abscessus complex (MABSC), is one of the most resistant pathogens as it possesses acquired and innate drug resistance. In the last years, MABSC was divided into three subspecies: M. abscessus subsp. abscessus, M. abscessus subsp. bolletii in $M$. abscessus subsp. massiliense. It is known that the three subspecies have different resistance profiles, hence correct species identification is clinically important. Three genes are important for MABSC resistance: erm(41), rrl and rrs. Gene erm(41) encodes the inducible 23S rRNA methylase and contributes to inducible macrolide resistance. Two erm(41) sequevars depending on the $\mathrm{T} / \mathrm{C}$ polymorphism at nucleotide 28 , are present in the MABSC population. M. abscessus subsp. abscessus and M. abscessus subsp. bolletii harbour gene erm(41) with a $\mathrm{T}$ at the nucleotide position 28 that leads to inducible 
macrolide resistance. M. abscessus subsp. massiliense however, has due to a deletion in this region a nonfunctional gene and is therefore macrolide susceptible. Further, high level of macrolide resistance is caused by point mutations in the peptidyl-transferase-binding region of $r r l$ gene, which can be present in all three subspecies. The macrolide antibiotic clarithromycin was the drug of choice in last decade, and still is for cystic fibrosis ( $\mathrm{CF}$ ) patients. Aminoglycoside resistance is caused by single point mutations in the rrs gene encoding $16 \mathrm{~S}$ rRNA and is also present in all three MABSC subspecies [2, 5].

The aim of our study was to perform a retrospective analysis of all Slovenian MAC and MABSC isolates with new molecular test GenoType NTM-DR, which is known to successfully identify $M$. chimaera isolates and also enables mutation identification in $r r l$, rrs and $\operatorname{erm}(41)$ genes [2, 4]. Our purpose was therefore to identify how many $M$. chimaera isolates were misidentified as $M$. intracellulare and to estimate how many isolates are resistant to macrolides and aminoglycosides and which mutations are prevalent in Slovenia. Moreover, information about clinical relevance of isolates was obtained.

\section{Materials and Methods}

In total 133 clinical isolates (obtained from 126 patients in the period from January 2007 to September 2016) from the Slovenian National Mycobacterial Collection at the Clinic Golnik were included in our county-wide survey. Clinical isolates were retrieved from 70 male and 56 female patients. Fisher's exact test was used to statistically evaluate the data related to clinical relevance. The threshold for statistical significance was set at a $\mathrm{P}$ value of $<0.05$. All isolates were previously identified with the diagnostic test GenoType CM/AS (Hain Lifescience, Nehren, Germany) as MABSC $(\mathrm{n}=31)$ or $M$. intracelullare $(\mathrm{n}=102)$. The previously used test cannot differentiate subspecies in MABSC and $M$. intracelullare from the closely related species $M$. chimaera. All investigated isolates were stored at $-20^{\circ} \mathrm{C}$ on glass beads and subcultured on Löwenstein-Jensen medium or Middlebrook 7 H10 agar plates. Total DNA was extracted from two loops of mycobacterial culture resuspended in 0,3 mL of sterile water. Cell lysis in the mycobacterial culture was done with incubation at $95^{\circ} \mathrm{C}$ for 20 minutes followed by sonication for 15 minutes. Samples were centrifuged at maximum speed 14000 RPM for 5 minutes. Supernatant with the extracted DNA was used for GenoType NTM-DR. PCR protocol and DNA hybridisation, was done according to manufacturer instructions as previously described [6].

\section{Results and Discussion}

In Slovenia in the last decade, the number of NTM isolates is increasing [12]. In the period 20002016 MAC and MABSC isolates were second and seventh most frequently isolated NTM in Slovenia, respectively. A similar trend - increasing number of NTM's - was noticed in other countries around the world too [10].

Our nation-wide analysis of 102 MAC isolates showed that $53 / 102(52 \%)$ isolates belonged to $M$. intracellulare and $49 / 102$ (48\%) isolates belonged to $M$. chimaera. We can therefore conclude that $M$. chimaera is nearly as common in our country as $M$. intracellulare. Schweickert et al. [9] reported that in Germany almost $86 \%$ of previously identified species as $M$. intracelullare are actually $M$. chimaera. Mok et al. [4] reported data from Ireland where 55\% of $M$. intracelullare isolates were misidentified and are actually $M$. chimaera. Our study showed that $M$. intracelullare was more often clinically relevant than $M$. chimaera (29\% vs. $6 \%$ of clinical isolates, respectively). Our obtained results are concordant with results of Schweickert et al. [9] and in contrary with Tortoli et al. [11] who proposed M. chimaera strains as more clinically relevant than other MAC species.

Retrospective analysis of Slovenian MABSC isolates from January 2007 to September 2016 showed that predominant species in our country was M. abscessus subsp. abscessus 24/31 (77.4\%), followed by $M$. abscessus subsp. bolletii 4/31 (12.9\%) and M. abscessus subsp. massiliense 3/31 (9.7\%). Our results are comparable with other countries in Europe

Table. Isolates of $M$. abscessus complex, $M$. intracellulare and included in the study presented by patients status and clinical relevance

\begin{tabular}{|l|c|c|c|c|}
\hline \multirow{2}{*}{ Mycobacterial species } & \multicolumn{2}{|c|}{ All patients } & \multicolumn{2}{c|}{ Cystic fibrosis patients } \\
\cline { 2 - 5 } & $\begin{array}{c}\text { No. of all } \\
\text { isolates }\end{array}$ & $\begin{array}{c}\text { No. (\%) of CR } \\
\text { isolates }\end{array}$ & $\begin{array}{c}\text { No. (\%) of all } \\
\text { isolates }\end{array}$ & $\begin{array}{c}\text { No. (\%) of CR } \\
\text { isolates }\end{array}$ \\
\hline M. abscessus subsp. abscessus & 24 & $7(29.1)$ & $4(16.7)$ & $4(16.7)$ \\
\hline M. abscessus subsp. massiliense & 4 & 0 & 0 & 0 \\
\hline M. abscessus subsp. bolletii & 3 & $1(33.3)$ & 0 & 0 \\
\hline M. intracellulare & 53 & $15(28.3)^{\star}$ & 0 & 0 \\
\hline M. chimaera & 49 & $3(6.1)^{\star}$ & $3(6.1)$ & 0 \\
\hline Total & 133 & $26(19.5)$ & $7(5.2)$ & $4(57.1)$ \\
\hline
\end{tabular}

$P$ values obtained following Fisher exact test are indicated by asterisks as follows: * $P<0.05$; CR: clinically relevant 
and in US, where M. abscessus subsp. abscessus represents around $45-65 \%$ of all MABSC isolates [7, 13]. Meanwhile in East Asia, the percentage of MABSC isolates is much higher among all NTM isolates. Furthermore, Asian countries also report M. abscessus subsp. abscessus as frequently isolated as M. abscessus subsp. massiliense [3] Our hypothesis was also that $M$. abscessus subsp. bolletii is rarest subspecies among MABSC in Slovenia, which would be concordant with results yielded in other studies [3, 7, 13]. Our hypothesis failed, but the number of samples was relatively small so in future more isolates will be need to be tested to confirm it.

Molecular analysis of resistance genes in MABSC showed that all 4/4 (100\%) M. abscessus subsp. bolletiii and 22/24 (92\%) M. abscessus subsp. abscessus had the $\mathrm{T}$ polymorphism at position 28 in $\operatorname{erm}(41)$ gene, which leads to inducible resistance to macrolides. All 3/3 (100\%) M. abscessus subsp. massiliense isolates also had the $\mathrm{T}$ polymorphism in erm(41) gene but due to deletion in this gene, isolates did not show inducible resistance to macrolides. No isolate of MABSC had a point mutation in $r r l$ gene or in $r r s$ gene. Thus, it can be concluded that high percentage of MABSC isolates can develop inducible macrolide resistance but highlevel macrolide resistance is not present at the moment. None of Slovenian MABSC isolates from the study had aminoglycoside resistance.
Also in MAC isolates no mutation in $r r l$ nor $r r s$ gene was detected. Based on this observation it can be concluded that all analysed MAC isolates were sensitive to both, macrolides and aminoglycosides with molecular methods.

Slovenian $M$. intracellulare isolates were found to be statistically significantly more clinical relevant than $M$. chimaera. None of $M$. intracellulare isolates was obtained from CF patient specimens. On the other hand, three of M. chimaera isolates were isolated from CF patient specimens, but were not clinically relevant. Higher percentage of $M$. abscessus subsp. abscessus isolates were found as clinical relevant, but with no statistical significance $(\mathrm{P}>0,05)$. Furthermore, M. abscessus subsp. abscessus was isolated from $\mathrm{CF}$ patients too (see Table).

To sum up, in Slovenia the number of MABSC isolates is slowly increasing, with $M$. abscessus subsp. abscessus being predominant subspecies. M. abscessus subsp. abscessus subspecies is the only subspecies isolated from specimens from patients with CF. Our MABSC isolates have high proportion of inducible resistance to macrolides. This fact needs to be considered when treating patients with MABSC infections, especially $\mathrm{CF}$ patients. $M$. intracellulare was a slightly more frequently isolated from human specimens than $M$. chimaera, and was more often clinically relevant in the last 10 years.

\section{Список литературы/References}

1. Falkinham J.O. Surrounded by mycobacteria: nontuberculous mycobacteria in the human environment. J. App. Microbiol., 2009, vol. 107, no. 2, pp. 356-367. doi: 10.1111/j.1365-2672.2009.04161.x

2. Kehrmann J., Kurt N., Rueger K., Bange F.C., Buer J. GenoType NTM-DR for identifying Mycobacterium abscessus subspecies and determining molecular resistance. J. Clin. Microbiol., 2016, vol. 54, no. 6, pp. 1653-1655. doi: 10.1128/JCM.00147-16

3. Kim H.Y., Kook Y., Yun Y.J., Park C.G., Lee N.Y., Shim T.S., Kim B.J., Kook Y.H. Proportions of Mycobacterium massiliense and Mycobacterium bolletii strains among Korean Mycobacterium chelonae-Mycobacterium abscessus group isolates. J. Clin. Microbiol., 2008, vol. 46, pp. 3384-3390. doi: 10.1128/JCM.00319-08

4. Mok S., Rogers T.R., Fitzgibbon M. Evaluation of GenoType NTM-DR assay for identification of Mycobacterium chimaera. J. Clin. Microbiol., 2017, vol. 55, no. 6, pp. 1821-1826. doi: 10.1128/JCM.00009-17

5. Mougari F., Bouziane F., Crockett F., Nessar R., Chau F., Veziris N., Sapriel G., Raskine L., Cambau E. Selection of resistance to clarithromycin in Mycobacterium abscessus subspecies. Antimicrob. Agents Chemother., 2016, vol. 61, no. 1, pp. 9. doi: 10.1128/ AAC.00943-16

6. Mougari F., Loiseau J., Veziris N., Bernard C., Bercot B., Sougakoff W., Jarlier V., Raskine L., Cambau E. Evaluation of the new GenoType NTM-DR kit for the molecular detection of antimicrobial resistance in non-tuberculous mycobacteria. J. Antimicrob. Chemother., 2017, vol. 72, no. 6, pp. 1669-1677. doi: 10.1093/jac/dkx021

7. Roux A.-L., Catherinot E., Ripoll F., Soismier N., Macheras E., Ravilly S., Bellis G., Vibet M.-A., Le Roux E., Lemonnier L., Gutierrez C., Vincent V., Fauroux B., Rottman M., Guillemot D., Gaillard J.L. Multicenter study of prevalence of nontuberculous mycobacteria in patients with cystic fibrosis in France. J. Clin. Microbiol., 2009, vol. 47, pp. 4124-4128. doi: 10.1128/JCM.01257-09

8. Sax H., Bloemberg G., Hasse B., Sommerstein R., Kohler P., Achermann Y., Rössle M., Falk V., Kuster P.S., Böttger C.E., Weber R. Prolonged outbreak of Mycobacterium chimaera infection after open- chest heart surgery. Clin. Infect. Dis., 2015, vol. 61, no. 1, pp. 67-75. doi: 10.1093/cid/civ198

9. Schweickert B., Goldenberg O., Richter E., Göbel U. B., Petrich A., Buchholz P., Moter A. Occurrence and clinical relevance of Mycobacterium chimaera sp. nov., Germany. Emerg. Infect. Dis., 2008, vol. 14, no. 9, pp. 1443-1446. doi: 10.3201/ eid1409.071032: 1443-1446

10. Stout J.E., Koh W.J., Yew W.W. Update on pulmonary disease due to non-tuberculous mycobacteria. Int. J. Infect. Dis., 2016, vol. 45, pp. 123-134. doi: 10.1016/j.ijid.2016.03.006

11. Tortoli E., Rindi L., Garcia M.J., Chiaradonna P., Dei R., Garzelli C., Kroppenstedt R.M., Lari N., Mattei R., Mariottini A., Mazzarelli G., Murcia M.I., Nanetti A., Piccoli P., Scarparo C. Proposal to elevate the genetic variant MAC-A, included in the Mycobacterium avium complex, to species rank as Mycobacterium chimaera sp. nov.. Int. J. Syst. Evol. Microbiol., 2004, vol. 54, no. 4, pp. 1277-1285. doi: 10.1099/ijs.0.02777-0 
12. Van der Werf M.J., Ködmön C., Katalinić-Janković V., Kummik T., Soini H., Richter E., Papaventsis D., Tortoli E., Perrin M., van Soolingen D., Žolnir-Dovč M., Thomsen V.Ø. Inventory study of non-tuberculous mycobacteria in the European Union. BMC Infect. Dis., 2014, vol. 14, no. 62. doi: 10.1186/1471-2334-14-62

13. Zelazny A.M., Root J.M., Shea Y.R., Colombo R.E., Shamputa I.C., Stock F., Conlan S., McNulty S., Brown-Elliott B.A., Wallace R.J. Jr., Olivier K.N., Holland S.M., Sampaio E.P. Cohort study of molecular identification and typing of Mycobacterium abscessus, Mycobacterium massiliense, and Mycobacterium bolletii. J. Clin. Microbiol., 2009, vol. 47, no. 7, pp. 1985-1995. doi: $10.1128 / J C M .01688-08$

\section{Авторы:}

Труден С., магистр, аналитик Национальной микобактериологической референс-лаборатории,

Университетская клиника респираторных и аллергических заболеваний, Голник, Словения;

Жолнир-Довч М., к.б.н., зав. Национальной микобактериологической референс-лабораторией, Университетская клиника респираторных и аллергических заболеваний, Голник, Словения;

Содья Э., к.б.н., научный сотрудник Национальной микобактериологической референс-лаборатории, Университетская клиника респираторных и аллергических заболеваний, Голник, Словения;

Старчич Эрьявец М., к.б.н., профессор молекулярной биологии, ассистент отдела биологии биотехнического факультета Люблянского университета, Любляна, Словения.

\section{Authors:}

Truden S., MSc, Analytics, National Reference Laboratory for Mycobacteria, University Clinic of Respiratory and Allergic Diseases Golnik, Golnik, Slovenia;

Žolnir-Dovč M., PhD, Head of National Reference Laboratory for Mycobacteria, University Clinic of Respiratory and Allergic Diseases Golnik, Golnik, Slovenia;

Sodja E., PhD, Research Associate, National Reference Laboratory for Mycobacteria, University Clinic of Respiratory and Allergic Diseases Golnik, Golnik, Slovenia;

Starčič Erjavec M., PhD, Full Professor for Molecular Biology, Teaching Assistant, Department of Biology, Biotechnical Faculty, University of Ljubljana, Ljubljana, Slovenia. 